\title{
Testing the Interface Hypothesis: The evidence from fossilized errors in the use of Turkish case markers
}

\author{
Elena Antonova-Ünlü \\ Hacettepe University \\ elenaunlu@gmail.com
}

\begin{abstract}
Sorace \& Filiaci (2006) proposed the Interface Hypothesis (IH), according to which interface structures requiring interface between syntax and other cognitive domains are more likely to be vulnerable to incomplete acquisition and fossilization than structures that involve syntactic knowledge only. The aim of this study is to provide a piece of evidence validating or rejecting the $\mathrm{IH}$ by investigating the use of case markers in Turkish by native speakers of Russian who are highly proficient speakers of Turkish and have been residing in Turkey for a long period. Fictional narratives are used in the study as the tool for data collection. The findings reveal that the participants demonstrate native-like use of Turkish case markers the production of which does not involve external interface. The use of case markers of direct objects, which involves the activation of external interface, is marked with fossilized errors and/or incomplete acquisition in the production of the participants. The findings of the study can be used as a piece of evidence in favor of the $\mathrm{IH}$.

Keywords: Interface Hypothesis, case markers, Turkish, native speakers of Russian
\end{abstract}

\section{Introduction}

Numerous studies of bilingual language acquisition have provided quite a solid piece of evidence that in L2 end-states some phenomena are more subject to fossilization and incomplete acquisition. In order to account for such patterns of "instability" and "residual optionality" in L2 end-states, Sorace \& Filiaci (2006) tested the interpretation of Italian pronominal subjects in native-like L2 Italian speakers and proposed the Interface Hypothesis (IH), which states that interface structures requiring interface between syntax and other cognitive domains are more likely to be vulnerable to incomplete acquisition than structures that involve syntactic knowledge only. Initially suggested for the very advanced level of ultimate attainment in $\mathrm{L} 2$ acquisition, the $\mathrm{IH}$ has been expanded to bilingual first language acquisition (BFLA) and initial stages of L1 attrition. Several studies (Mueller \& Hulk, 2001; Paradis \& Navarro, 2003; Tsimpli, Sorace, Heycock \& Filiaci, 2004; Belletti, Bennati \& Sorace, 2007; Haznedar, 2007) provided evidence supporting the IH by demonstrating that at 
syntax-discourse interface, language behavior of bilingual children in BFLA, as well as of adult learners at very advanced levels of L2 attainment differs from that of native speakers, and that syntax-discourse interface structures are vulnerable at the very early stages of attrition.

Further, White (2007) elaborated the hypothesis and argued for a dichotomy between interface structures, dividing them into external and internal. External interfaces, those involving external domains, for example, syntax and discourse were suggested to be more vulnerable to incomplete acquisition, while internal interfaces, such as syntax-semantic, morphologysemantics, would be easier to acquire completely. However, research on bilingual development has not only demonstrated that the division of interfaces into internal and external cannot always account for optionality and instability of the domain (for example, the internal morphology-syntax interface has long been argued to be problematic both in adult and child bilingual contexts (see White, 2003) or structures within the same external interface have been found to differ in respect of optionality in L2 acquisition (Tsimpli \& Sorace, 2006), but has also challenged the IH itself by providing evidence that certain structures belonging to syntax-discourse interface, such as object clitics in L2 Bulgarian (Ivanov, 2009) and null and overt subject pronouns in L2 Spanish (Rothman, 2008), are not subject to optionality and they can be acquired in a native-like manner.

Recently, Sorace $(2011,2012)$ pinning down the concept of the IH, acknowledged that the major focus of the IH research had been on anaphora resolution in different languages, and that more data presenting testing of different interface structures and structures belonging to multiple interfaces, like semantic-discourse-morpho-syntax, were needed. Rather than classifying structures as belonging to a certain type of interface, it would be more important to identify structures posing different kinds of difficulties to bilinguals and to discuss their sources.

Concerning the possible sources of optionality and instability occurring in bilinguals' use of structures that are vulnerable to interface conditions two options have been proposed: the representative account supposed that "there are differences between bilinguals and monolinguals at the level of knowledge representations, ... because one of the grammatical systems affects the other" (Sorace, 2011, p. 13); the processing resources account considered the differences between monolinguals and bilinguals at the level of processing strategies required in the use of interface structures. The first account alone is not able to account for differences between monolinguals and bilinguals because several studies Lozano (2006); Margaza \& Bel (2006); Sorace, Serratrice, Filiaci, \& Baldo, (2009) demonstrated that regardless of whether the bilinguals' L1 is null subject or not, the process of anaphora resolution in their other null subject language is affected. In this line, there is 
a possibility that revealed differences between monolinguals and bilinguals at the syntax-pragmatic interface may reflect differences in processing rather than only cross-linguistic influence (Sorace \& Serrtrice, 2009; Sorace, 2011).

The aim of this study is to contribute to the discussion about the IH by providing another piece of empirical data related to the acquisition of case markers in Turkish by native speakers of Russian who are highly proficient speakers of Turkish and have been residing in Turkey for a long period. The choice of the Turkish case system in relation to the IH is determined by the fact that the selection of case marking for the direct object in Turkish (case non-marked or accusative) is an interesting case of multiple interface phenomenon (morpho-syntax, semantic and discourse) and it may be driven, in particular cases, by discourse-related conditions: for example, the use of the accusative marker with previously mentioned and/or definite direct objects, conversely, the use of a zero marker with first mentioned and/or indefinite direct objects (Example 1, a, b).

(1) a. Yaşlı bir adam hazine bul-muş. ${ }^{1}$ old one man-N-M treasure-N-M find-PER.EV-3P.SG (indef. obj.)

'An old man found treasure.'

b. Bütün haziney-i kimsesiz çocukla-ra bağışlamış. all treasure-ACC orphan children-DAT donate-PER.EV-3P.SG (def. obj.)

'He donated all the treasure to orphan children.'

As it is evident from the example above, the selection of case marking for direct objects, case non-marked or accusative, in Turkish may be determined on the basis of known or unknown information/ shared or unshared knowledge of the speaker and the hearer. The use of the other case markers in Turkish, on the other hand, is not governed by discourse-related conditions and, therefore, they cannot be dropped.

Thus, relying on the $\mathrm{IH}$ and findings of the studies supporting it, two hypotheses can be formulated:

1 Abbreviations: ABIL: Ability, ABL: Ablative case, ACC: Accusative case, AOR: Aorist tense, COM: Commitative, CON: Converb, DAT: Dative case, EV: Evidential, GEN: Genitive, IMPER: Imperfective, INST: Instrumental, LOC: Locative case, NEG: Negator, N-M: Case Non-Marked, NOM: Nominalizer, P: Person, PAST: Past tense, PER: Perfective, PL: Plural, POSS: Possessive marker, Q: Question marker, SG: Singular 
1. Advanced users of L2 Turkish will reveal native-like use of Turkish cases the production of which does not involve external discourse interfaces.

2. The use of the accusative case in the production of advanced users of L2 Turkish will be marked with fossilized errors and/or incomplete acquisition as the case marking of direct object in Turkish requires the activation of the external discourse interface.

The study is structured as follows. First, the description of the case system in Turkish and its acquisition in various learning contexts will be described. Second, since the advanced users of L2 Turkish participating in the study are native speakers of Russian, the description of the typological characteristics of Russian with a focus on the case system is necessary in order to examine the potential cross-linguistic effect as a possible source of optionality and instability. Third, the present study, including the participants, the method of data collection and analysis will be introduced; finally results and discussion will follow.

\section{Case Marking in Turkish}

The function of case marking (or its absence) is to show the relationship between the noun phrase to which it is attached and other sentence constituents (Göksel \& Kerslake, 2005, p.173). Turkish has six case markers. Table 1 below presents the Turkish case markers, their main functions with examples.

Table 1. The system of case markers in the Turkish language (based on Göksel \& Kerslake, 2005)

\begin{tabular}{|c|c|c|c|}
\hline Case & Suffix & Main functions & Example \\
\hline Locative & $-\mathrm{DA}$ & $\begin{array}{l}\text { The time/place adverbial, the } \\
\text { oblique object of certain verbs, a } \\
\text { subject complement, the compound } \\
\text { adjectival modifier. }\end{array}$ & $\begin{array}{l}\text { Dere-de } \\
\text { '(in) the } \\
\text { river'; } \\
\text { çocuk-ta } \\
\text { '(at) the } \\
\text { child' }\end{array}$ \\
\hline Ablative & -DAn & $\begin{array}{l}\text { The adverbial of place/time, the } \\
\text { oblique object of certain verbs, the } \\
\text { complement of certain } \\
\text { postpositions, adjectives. }\end{array}$ & $\begin{array}{l}\text { Dere-den } \\
\text { '(from) the } \\
\text { river; } \\
\text { çocuk-tan } \\
\text { '(from) the } \\
\text { child' }\end{array}$ \\
\hline
\end{tabular}




\begin{tabular}{|c|c|c|c|}
\hline Genitive & $-(\mathrm{n}) \operatorname{In} /-\operatorname{Im}$ & $\begin{array}{l}\text { The modifier in a genitive- } \\
\text { possessive construction, the types } \\
\text { of non-finite subordinate (noun, } \\
\text { relative) clauses. }\end{array}$ & $\begin{array}{l}\text { Dere-nin } \\
\text { 'of the } \\
\text { river'; } \\
\text { çocuğ-un } \\
\text { 'the } \\
\text { child's', }\end{array}$ \\
\hline Instrumental & $-(\mathrm{y}) 1 \mathrm{~A}$ & $\begin{array}{l}\text { The comitative and instrumental } \\
\text { function }\end{array}$ & $\begin{array}{l}\text { Dere-yle } \\
\text { 'with the } \\
\text { book'; çocuk- } \\
\text { la 'with the } \\
\text { child' }\end{array}$ \\
\hline Dative & $-(\mathrm{y}) \mathrm{A}$ & $\begin{array}{l}\text { The recipient/beneficiary of an } \\
\text { action, the destination/target of an } \\
\text { action, purpose, the oblique object } \\
\text { of certain verbs, the cause of a } \\
\text { causative construction. }\end{array}$ & $\begin{array}{l}\text { Dere-ye } \\
\text { '(to) the } \\
\text { river'; } \\
\text { çocuğ-a } \\
\text { '(to) the } \\
\text { child' }\end{array}$ \\
\hline Accusative & $-(\mathrm{y}) \mathrm{I}$ & Direct object. & $\begin{array}{l}\text { Dere-yi } \\
\text { 'the river'; } \\
\text { çocuğ- } u \\
\text { 'the child' }\end{array}$ \\
\hline
\end{tabular}

These case markers are used with nouns, personal and demonstrative pronouns, question words, and derived nominal. Of all case markers in Turkish, the accusative is the only one that sometimes can be non-obligatory, leaving some direct objects in the non-case-marked form. The accusative case marker is obligatory for marking a direct object in cases where the direct object is definite, that is whether it has been previously mentioned and/or is the focus of the utterance (Example 2). The accusative case marker is also necessary where an indefinite direct object precedes the verb but does not occupy the immediately pre-verbal position (Example 3). An indefinite direct object that is in the immediately pre-verbal position commonly is non-case-marked (Example 4). However, if an indefinite direct object is marked with a possessive suffix or belongs to plural genetic or implied groups, the accusative case marker is required even in the immediate pre-verbal position (Example 5) (for detailed discussion, see Erguvanl1, 1984; Enç, 1991; Göksel, 1993; Ketrez, 2005; Kornfilt, 1997; Nakipoğlu, 2009; Öztürk, 2005, 2009).
(2) Senin iste-di $\breve{g}$-in
kitab-1
getir-di-m
your want-NOM-2P.SG book-ACC
bring-PAST-1P.SG
'I have brought the book you asked for.' 
(3) Dondurma-y1 her gün yi-yebil-ir-im! ice-cream-ACC every day-N-M eat-ABIL-AOR-1P.SG 'I can eat ice-cream every day.'

(4) Komşu-m bir araba al-dı. neighbor-POSS.1P one car-N-M buy-PAST-3P.SG 'My neighbor has bought a car.'

(5) Toplantı çok kalabalık-tı. Çoğu kişi-yi Meeting-N-M very crowded-PAST most people-ACC tani-mi-yor-du-m. know-NEG-IMPER-PAST-1P.SG

'The meeting room was very crowded. I did not know many people there.'

Thus, as it is evident from the explanation above, the accusative case marking in Turkish involves multiple interfaces, such as morphology, syntax, semantics and discourse.

\section{Acquisition of Turkish Case Markers in Various Contexts}

The acquisition of case markers in Turkish has been investigated in various acquisitional contexts, namely: monolingual, bilingual and in Turkish as a foreign language context. In the monolingual context, the studies examining the acquisition of case morphology (Ekmekçi, 1979; Aksu-Koç \& Slobin, 1985; Sofu, 1989; Topbaş, Maviş \& Başal, 1996; Aksu-Koç \& Ketrez, 2002; Ketrez, 2004,2005 , 2006) revealed that monolingual Turkish children start using case endings to mark grammatical roles of nominals in obligatory contexts before the age of 2;0. They rely on the inflectional system, which is regular and transparent, but not on the word order in the sentence as monolingual English children do. Though Turkish children acquire case markers effectively at an early age, the full mastery takes some more time. The correct use of case markers in the production of monolingual Turkish children after 2;0 is above $50 \%$ for all cases though none of them is produced $100 \%$ correctly. Of all cases, the accusative case emerges the latest and, though it is productively used after its first appearance, numerous mistakes in the use of case markers of the direct object (accusative versus case non-marked) appear in the children's production even after the age of four-five (Ketrez, 2004).

The use of Turkish cases of bilingual children was investigated by Heijden \& Verhoeven (1994) and Akyol (2009), who looked into the acquisition of Turkish by Turkish-Dutch and English-Turkish children, respectively. The researchers found out that at the initial stages, their bilingual participants tend to make errors while using most of Turkish cases; nevertheless, with the expansion of the children's linguistic repertoire, errors decrease and mostly disappear. The studies recorded that the bilingual children, by and large, 
follow the monolingual pattern of acquisition and they make errors similar to those of their monolingual Turkish counterparts. For instance, similarly to monolinguals, the bilingual participants tend to overgeneralize rules of the genitive case formation on some lexical items and, therefore, overuse possessive markers. Yet, some of the bilinguals' erroneous structures can also be attributed to the influence of the other language in their repertoire.

The use of cases in Turkish as L2 was in the scope of studies examining the use of Turkish grammatical morphemes based on the spontaneous production and experimental data of L2 Turkish learners (Akdoğan, 1993; Gürel, 2000; Haznedar, 2006; Güven, 2007; Papadopoulou, Varlokosta, Spyropoulos, Kaili, Prokou \& Revithiadou, 2011; Altunkol \& Balc1, 2013). The researchers focused on difficulties foreign learners of various L1 backgrounds and levels of proficiency (from elementary to advanced) encounter with Turkish cases, and demonstrated that L2 learners of Turkish experience a lot of problems with the Turkish cases system, which may persist even at the very advance level of proficiency in L2 Turkish. The learners tend to omit case morphemes rather than substitute them. The studies were consistent in their findings revealing that the accusative and dative are very problematic cases even for intermediate and very advanced learners of Turkish; however, concerning the locative and ablative cases, their findings varied. While some of the studies (Altunkol \& Balc1, 2013) reported that the participants are able to acquire these cases successfully, Haznedar (2006) reported $96 \%$ and $58 \%$ of errors for the ablative and locative cases respectively in the data of the advanced user of Turkish.

\section{Case Marking in Russian}

Russian is a strongly inflecting language belonging to the West-Slavic languages and possessing a very complex noun and verb morphology, which comprises quite a lot of categories such as case, number and gender for nouns and aspect, tense, mode for verbs, all of which are richly developed. Russian morphology is fusional and it is marked with numerous morphophonemic alterations. There is an extensive agreement system between different parts of speech in the sentence. Russian, is known for so called free-word order, and the place of major constituents in the sentence is determined not by their syntactical functioning but by pragmatic factors such as topic and focus. Russian does not have equivalents to the English definite and indefinite articles, "so that a noun phrase like собáka [sobáka] (dog) will sometimes be translated as (a dog), sometimes as (the dog)" (Comrie, 1987, p. 285). Russian cases mark syntactic relations within a sentence that is they indicate whether a noun or a pronoun is a subject, a predicate, an object or an attribute in the sentence. Traditionally, Russian has six primary cases: those are nominative, genitive, 
dative, accusative, instrumental and prepositional. The case marking is not uniform for all nouns, but there is a set of patterns, or declensions, and each noun is assigned to one of these classes (Timberlake 2004). Corbett (1982), Corbett (1991), Corbett \& Fraser (1993) distinguish four possible types of declensions of Russian nouns, which account for all but about twenty of all declinable nouns (see Table 2).

Table 2. Major noun declension classes of Russian

\begin{tabular}{|c|c|c|c|c|}
\hline Noun & $\begin{array}{l}\text { I. } \\
\text { Закон } \\
\text { [Zakon] } \\
\text { (Law) }\end{array}$ & $\begin{array}{l}\text { II. } \\
\text { Комната } \\
\text { [Komnata] } \\
\text { (Room) }\end{array}$ & $\begin{array}{l}\text { III. } \\
\text { Kocmb } \\
\text { [Kost'] } \\
\text { (Bone) }\end{array}$ & $\begin{array}{l}\text { IV. } \\
\text { Buно } \\
\text { [Vino] } \\
\text { (Wine) }\end{array}$ \\
\hline \multicolumn{5}{|l|}{ Singular } \\
\hline \multirow[t]{2}{*}{ Nominative } & Закон & Комнат-а & Кость & Вин-о \\
\hline & Zakon & Komnat-a & Kost' & Vin-o \\
\hline \multirow[t]{2}{*}{ Genitive } & Закон-а & Комнат-ы & Кост-и & Вин-а \\
\hline & Zakon-a & Komnat-y & Kost-i & Vin-a \\
\hline \multirow[t]{2}{*}{ Dative } & Закон-у & Комнат-е & Кост-и & Вин-у \\
\hline & Zakon-u & Komnat-e & Kost-i & Vin-u \\
\hline \multirow[t]{2}{*}{ Accusative } & Закон & Комнат-у & Кость & Вин-о \\
\hline & Zakon & Komnat-u & Kost' & Vin-o \\
\hline \multirow[t]{2}{*}{ Instrumental } & Закон-ом & Комнат-ой & Кость-ю & Вин-ом \\
\hline & $\begin{array}{l}\text { Zakon- } \\
\text { om }\end{array}$ & Komnat-oj & Kost-ju & Vin-om \\
\hline \multirow[t]{2}{*}{ Prepositional } & Закон-е & Комнат-е & Кост-и & Вин-е \\
\hline & Zakon-e & Komnat-e & Kost-i & Vin-e \\
\hline \multicolumn{5}{|l|}{ Plural } \\
\hline \multirow[t]{2}{*}{ Nominative } & Закон-ы & Комнат-ы & Кост-и & Вин-а \\
\hline & Zakon-y & Komnat-y & Kost-i & Vin-a \\
\hline \multirow[t]{2}{*}{ Genitive } & Закон-ов & Комнат & Кост-ей & Вин \\
\hline & Zakon-ov & Komnata & Kost-ej & Vin \\
\hline \multirow[t]{2}{*}{ Dative } & Закон-ам & Комнат-ам & Кост-ям & Вин-ам \\
\hline & $\begin{array}{l}\text { Zakon- } \\
\text { am }\end{array}$ & Komnat-am & Kost-jam & Vin-am \\
\hline \multirow[t]{2}{*}{ Accusative } & Закон-ы & Комнат-ы & Кост-и & Вин-а \\
\hline & zakon-y & Komnat-y & Kost-i & Vin-a \\
\hline \multirow[t]{2}{*}{ Instrumental } & Закон- & Комнат-ами & Кост-ями & Вин-ами \\
\hline & $\begin{array}{l}\text { ами } \\
\text { Zakon- } \\
\text { ami }\end{array}$ & Komnat-ami & Kost-jami & Vin-ami \\
\hline \multirow[t]{2}{*}{ Prepositional } & Закон-ах & Комнат-ах & Кост-ях & Вин-ах \\
\hline & Zakon-ah & Komnat-ah & Kost-jah & Vin-ah \\
\hline
\end{tabular}


There is a certain correlation between phonology and the declension type. Nouns of declension I in the nominative case end in the consonant, either palatalized or non-palatalized, while declension II includes mainly nouns that end in the vowels $-a[-a],-я[-j a]$ in the nominative case; all the nouns in declension III have a palatalized stem, and nouns ending in $-o[-o]$, $-e[-e]$ belong to declension IV.

Every Russian case can indicate several functions, which depend on the following factors: 1) its morphological form; 2) its syntactic position; and 3) semantics. Relying on these factors, Russian cases are divided into two classes: syntactic (or grammatical) and semantic (or concrete) (Kurilovich, 1962). Grammatical cases, namely, accusative as a direct object, nominative as a subject and abnominal genitive, form the skeleton of the whole system of Indo-European languages. They fulfil main syntactic functions revealing basic subject-object relations. Semantic cases, on the other hand, are in a subordinate position in the system and their functions are determined mainly by semantics (Kurilovich 1962, p. 193-197). In many cases it is very difficult to figure out which case should be used as the government in phrases is very often determined by tradition, for instance, onаздывать на АCC [opazdyvat' na] (to be late for), сердиться на ACC [serdit'sja na] (to be angry with), смеяться над INST [smejat'sja nad] (to laugh at), обнимать ACC [obnimat'] (hug).

If to contrast the Russian and Turkish languages, which are available in the repertoire of the participants, it stands out that both languages possess case systems consisting of six case markers, yet the Turkish case system, lacking declension classes, looks more straight-forward and transparent. Although grammatical cases fulfilling main syntactic functions are available in both language: nominative for subjects, accusative for direct objects, dative for oblique objects and genitive for genitive-possessive constructions, there are a lot of differences in the use of cases in similar surface structures between Turkish and Russian. For example, the genitive case in Russian fulfils the function of locative designation, which corresponds to Turkish structures with the ablative case; or the instrumental case in Russian, along with the commitative and instrumental functions available in Turkish, is also used for locative and temporal designation and can be the predicate of the sentence (Kamynina, 1999). Moreover, there are a lot of surface structures where the agreement between the verb and the noun is determined by tradition and is not the same in the languages. Example 6 below presents some of such cases.

(6) Russian

Обнимать

Turkish

Звонить

[obnimat'-ACC] [zvonit'-DAT]

Sarılmak DAT

English

Решать(ся) (на) [rešat'(sja) (na)-ACC]

Aramak ACC

Hug

Karar vermek DAT Decide 
Another difference between Russian and Turkish, which is relevant to this study, is the marking of definiteness/indefiniteness. While definiteness/indefiniteness is not inflected in Russian, in Turkish, definiteness is marked by the accusative case in direct objects.

\section{Method}

\subsection{Stimuli}

Fictional narratives are used in the study for collecting the data. Narratives are commonly used in the multilingual research examining morphological development of multilinguals (Berman, 1999; Kupersmitt \& Berman, 2001; Lanza, 2001; Viberg, 2001; Pavlenko, 2003 among others). The participants of the study are interviewed individually. Firstly, they are questioned to provide personal and language background information. Then, the participants are asked to narrate a suggested film in Turkish in a written form. The name of the film is "Juno". The brief summary of the film is given below:

Juno, a fifteen-year-old protagonist, gets pregnant and plans to give her baby up for adoption. For this purpose, she finds a young wealthy couple. However, the husband is not willing and ready to become a father; therefore, he decides to get divorced. At the end of the film, Juno gives the baby to the woman as a single mother.

The following instruction is given to the participants: "Here is a film named "Juno". Would you, please, watch the film and write down what happened in the film in Turkish". After narrating in Turkish, in order to be able to examine the role of their L1, the participants are asked to reproduce their narratives in Russian. The instruction is given in Turkish to activate the monolingual Turkish mode of the participants (Grosjean, 2001). The participants write their narratives in pen and they are not restricted in time.

\subsection{Participants}

The subjects of the study are seven Russian adults (all females) at the age of 29 to $41(M=36,2)$, who arrived in Turkey after getting married in Russia to a native-speaker of Turkish, who had worked there for a construction company. The participants have been living in Turkey for 8 to 15 years $(M=13,4)$ by the moment of the data collection. Three of the participants are graduates of professional schools (musical, medical and pedagogical) and four of them graduated from universities (law, medical and financial). After arriving in Turkey for a permanent residence in their twenties $(M=22.1)$, the participants attended a course of the Turkish language at various institutions in the country, 
at the end of which they took a comprehensive proficiency exam including reading, speaking, listening, composition writing and grammar sections, and were certified as advanced users of the Turkish language. The participants report that they have mostly been using Turkish in their everyday communication during their residence in the country. Though the participants had English as a foreign language classes during their secondary school, all of them state that they have never read books and periodicals or watched TV programmes or films in this language. None of them has been to an English speaking country for more than a week. Though they have never taken a proficiency exam in English, they consider their levels of knowledge as elementary or below. Based on the self-reports of the participants about their knowledge of the languages, I will refer to them as Russian-Turkish bilinguals. However, as it was highlighted by an anonymous reviewer, every language in mind might matter, therefore, I will return to the possible effect of elementary knowledge of English on the acquisition of Turkish cases by the RussianTurkish participants later.

The narratives obtained from the Russian-Turkish participants are compared with the baseline data coming from seven working Turkish nativespeaking married females who are at the age of 29 to $39(M=35)$ and come from an upper-middle class. The baseline group is given the analogous instruction to fulfil the same task.

\subsection{Data Analysis}

First the data are transcribed using the CHAT format of CHILDES. As the focus of the study is on fossilized errors and deviations from monolingual norms observed in the use of case markers in Turkish by the Russian-Turkish participants, error analysis is used as the main method of data analysis. Two native speakers of Turkish, who have degrees in Turkish linguistics, are asked to judge the narratives written by both Russian-Turkish and Turkish groups in terms of grammaticality and acceptability related to the use of Turkish case markers. The judges are asked to identify grammatically and ungrammatically used case markers, and provide an explanation for their evaluations. The judges are not informed about the background languages of the participants. Further, all the identified forms are categorized according to the following categories: 1 ) correct use 2) omission of the case marker; 3) replacement of the case marker with an incorrect one; 4) overuse of the case marker. In the "correct use" category, all the cases of the proper use of case markers are counted (Example 7 ); in the "omission of the case marker" category, all the cases where case markers are omitted are included (Example 8); in the category of the "replacement of the case marker with an incorrect one", all the cases where the required case is substituted with another one are included (Example 9); finally, 
in the category of the "overuse of the case marker", the cases where the case marker under the analysis is overused on a noun which does not require any case marking are considered (Example 10).

(7) Sen bu kitab-1 geçen hafta bitir-di-n mi? you this book-ACC last week finish-PAST-2P.SG Q 'Did you finish this book last week?'

(8) Sen bu *kitap-X geçen hafta bitir-di-n mi? you this *book-N-M last week finish-PAST-2P.SG Q 'Did you finish this book last week?'

(9) Sen bu *kitab-a geçen hafta bitir-di-n mi? you this *book-DAT last week finish-PAST-2P.SG Q 'Did you finish this book last week?'

(10) Sen bu kitab-1 geçen *hafta-da bitir-di-n mi? you this book-ACC last *week-LOC finish-PAST-2P.SG Q 'Did you finish this book last week?'

All the uses of the grammatical and ungrammatical case markers are counted. Then, the data coming from the Russian-Turkish group are compared with that of the native speakers of Turkish. Finally, in order to be able to speak about the influence of L1 Russian on the acquisition of cases in L2 Turkish, the data produced by the Russian-Turkish participants are compared with their production in L1 Russian.

\section{Results and Discussion}

The data analysis has revealed that all the Russian-Turkish and Turkish participants use all Turkish case markers productively as all of the cases are available in the data of each of the participants. However, while no single incorrect use of cases has been detected by the judges in the group of the native speakers of Turkish, the data coming from the Russian-Turkish participants have been reported to be marked with incorrect uses of some cases. Table 3 below represents the number of correct instances and their percentages in relation to the total uses of Turkish case markers observed in the RussianTurkish participants' production.

Table 3. Correct use of Turkish case markers by the Russian-Turkish participants

\begin{tabular}{lllllllllllllll}
\hline Participant & 1 & & 2 & & 3 & & 4 & & 5 & & 6 & & 7 \\
LOC & $\mathrm{N}$ & $\%$ & $\mathrm{~N}$ & $\%$ & $\mathrm{~N}$ & $\%$ & $\mathrm{~N}$ & $\%$ & $\mathrm{~N}$ & $\%$ & $\mathrm{~N}$ & $\%$ & $\mathrm{~N}$ & $\%$ \\
ABL & 7 & 100 & 7 & 100 & 16 & 100 & 6 & 100 & 3 & 100 & 7 & 100 & 4 & 100 \\
GEN & 2 & 100 & 2 & 100 & 2 & 100 & 6 & 100 & 4 & 100 & 4 & 100 & 5 & 100 \\
& 9 & 100 & 8 & 100 & 17 & 100 & 15 & 100 & 7 & 100 & 9 & 100 & 15 & 100
\end{tabular}




$\begin{array}{lllllllllllllll}\text { INST } & 4 & 100 & 4 & 100 & 6 & 100 & 4 & 100 & 13 & 100 & 4 & 100 & 5 & 100 \\ \text { DAT } & 18 & 94 & 16 & 100 & 21 & 95 & 17 & 94 & 17 & 94 & 14 & 100 & 16 & 94 \\ \text { ACC } & 20 & 77 & 15 & 88 & 20 & 74 & 25 & 86 & 13 & 72 & 11 & 85 & 15 & 83\end{array}$

In order to understand what difficulties the Russian-Turkish participants encounter while using cases in Turkish, each case marker has been analysed separately.

The data analysis has revealed that the use of the locative marker in the production of the Russian-Turkish participants is not marked with a single instance of omission, replacement or overuse, as it is evident from Table 4.

Table 4. The use of the locative case markers in the production of RussianTurkish bilinguals

\begin{tabular}{llllllll}
\hline Participants & 1 & 2 & 3 & 4 & 5 & 6 & 7 \\
\hline Total use $(100 \%)$ & 7 & 7 & 16 & 6 & 3 & 7 & 4 \\
Correct use & 7 & 7 & 16 & 6 & 3 & 7 & 4 \\
Correct use $(\%)$ & 100 & 100 & 100 & 100 & 100 & 100 & 100 \\
\hline
\end{tabular}

Example 11, taken from the Russian-Turkish participants' narratives, illustrates two cases of the locative case use.

(11) Film-de hikaye sonbahar-da başl1-yor. film-LOC story-N-M autumn-LOC start-IMPER.3P.SG

'The story of the film starts in autumn.'

The data analysis has revealed that the use of the ablative case marker in the production of the Russian-Turkish participants is also absolutely correct and no single instance of omission, replacement or overuse of the ablative case marker is found in the data. Table 5 presents the use of the ablative case marker of the Russian-Turkish participants.

Table 5. The use of the ablative case markers in the production of RussianTurkish bilinguals

\begin{tabular}{llllllll}
\hline Participants & 1 & 2 & 3 & 4 & 5 & 6 & 7 \\
\hline Total use (100\%) & 2 & 2 & 2 & 6 & 4 & 4 & 5 \\
Correct use & 2 & 2 & 2 & 6 & 4 & 4 & 5 \\
Correct use (\%) & 100 & 100 & 100 & 100 & 100 & 100 & 100 \\
\hline
\end{tabular}

Example 12 displays one of the uses of the ablative case marker from the data of the Russian-Turkish participants. 
(12) $\mathrm{Bu}$ ziyaret-ler-den bir-in-de onlar-1n these visit-PL-ABL one-POSS-LOC they-GEN çok mutlu ol-ma-dı̆̆-ın-1 anlı-yor. very happy be-NEG-NOM-POSS-ACC understand-IMPER-3P.SG 'During one of these visits, she understands that they are not a very happy couple.'

The genitive case marker appears in the data of the Russian-Turkish participants also absolutely correctly, as it is evident from Table 6 .

Table 6. The use of the genitive case markers in the production of RussianTurkish bilinguals

\begin{tabular}{llllllll}
\hline Participants & 1 & 2 & 3 & 4 & 5 & 6 & 7 \\
\hline Total use (100\%) & 9 & 8 & 17 & 15 & 7 & 9 & 15 \\
Correct use & 9 & 8 & 17 & 15 & 7 & 9 & 15 \\
Correct use (\%) & 100 & 100 & 100 & 100 & 100 & 100 & 100 \\
\hline
\end{tabular}

Example 13 illustrates one of the uses of the genitive case marker from the data of the Russian-Turkish participants.

(13) Çift-in dön-üp küçük bir not couple-GEN house-POSS-DAT return-CON small one note-N-M birak-1yor. leave-IMPER-3P.SG

'Having returned to the couple's house, she leaves a small note'.

No single omission, replacement or overuse has been observed in the use of the instrumental case marker in the data of the Russian-Turkish participants. Table 7 and Example 14 are illustrative.

Table 7. The use of the instrumental case markers in the production of RussianTurkish bilinguals

\begin{tabular}{llllllll}
\hline Participants & 1 & 2 & 3 & 4 & 5 & 6 & 7 \\
\hline Total use (100\%) & 4 & 4 & 6 & 4 & 13 & 4 & 5 \\
Correct use & 4 & 4 & 6 & 4 & 13 & 4 & 5 \\
Correct use (\%) & 100 & 100 & 100 & 100 & 100 & 100 & 100 \\
\hline
\end{tabular}

(14) Baba-s1-yla bu genç aile-yi ziyaret ed-iyor. father-POSS-INST/COM this young family-ACC visit-IMPER-3P.SG 'She visits this young family with her father.'

The absolute correct use of the locative, ablative, possessive and instrumental case markers of the Russian-Turkish participants allows me to conclude that the 
Russian-Turkish participants have completely acquired the use of these case markers and use them in a native-like manner while narrating in Turkish.

The analysis of the use of the dative case has revealed that all the RussianTurkish participants can use the dative case productively and the majority of the uses of the dative case (96\%) are correct. In order to explore whether the use of the dative case of the Russian-Turkish bilinguals statistically differs from that of the native speakers of Turkish, Mann-Whitney U test has been carried out. The test has revealed no significant difference in the use of the dative case markers between the groups $(U=19,500, p=.505)$. This allows me to infer that the Russian-Turkish participants have acquired the use of the dative case marker in their L2 Turkish.

Example 15 illustrates the correct use of the dative case marker from the Russian-Turkish data.

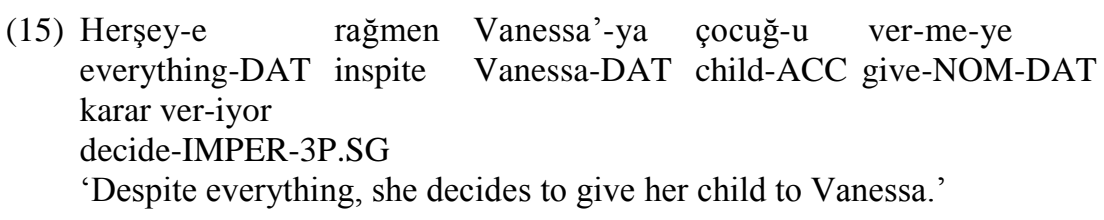

Notwithstanding the very high percentage of the correct use of the dative case in the data of the Russian-Turkish participants and the absence of the significant difference in the use of the dative case marker between the RussianTurkish and Turkish groups, it is necessary to state that five of the RussianTurkish participants make a single error while using the dative case marker. Table 8 demonstrates the number and percentages of correct uses, omissions, replacements and overuses of the dative case for each Russian-Turkish participant.

Table 8. The use of the dative case markers in the production of RussianTurkish bilinguals

\begin{tabular}{llllllll}
\hline Participants & 1 & 2 & 3 & 4 & 5 & 6 & 7 \\
\hline Total use (100\%) & 19 & 16 & 22 & 18 & 18 & 14 & 17 \\
Correct use & 18 & 16 & 21 & 17 & 17 & 14 & 16 \\
Correct use (\%) & 94 & 100 & 95 & 94 & 94 & 100 & 94 \\
Omission & 0 & 0 & 0 & 0 & 0 & 0 & 0 \\
Omission (\%) & 0 & 0 & 0 & 0 & 0 & 0 & 0 \\
Replacement & 1 & 0 & 1 & 1 & 1 & 0 & 1 \\
Replacement (\%) & 6 & 0 & 5 & 6 & 6 & 0 & 6 \\
Overuse & 0 & 0 & 0 & 0 & 0 & 0 & 0 \\
Overuse (\%) & 0 & 0 & 0 & 0 & 0 & 0 & 0 \\
\hline
\end{tabular}


As it is evident from Table 8, the Russian-Turkish participants neither omit nor overuse the dative case marker; yet, five out of seven participants replace the obligatory dative case marker with the accusative case only for once in their narratives. All the instances of the dative case replacements occur when the dative case marker appears in the function of the oblique object, as Example 16 below presents.

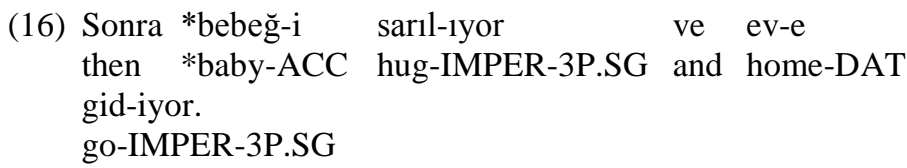

'After she hugs the baby and goes home'.

It is necessary to say that the few replacements of the dative case with the accusative as in Example 16 might be attributed to the influence of L1 Russian based on the contrastive analysis of the surface structures of Turkish and Russian (see Example 6).

Also, it is worth mentioning that all the instances of the replacements of the dative case marker with the accusative one appear in the data of the Russian-Turkish participants along with correct uses of the dative case marker with the same verbal forms. Such language behaviour has been reported in bilingual acquisition and the question of why erroneous forms perpetually appear along with the correct ones in the production of bi/multilinguals has been discussed several times (Grosjean, 2001; Meisel, 2007 among many others). It was suggested that such language behaviour of bi/multilinguals cannot be attributed to the inability to acquire the correct form, but most probably is related to the difficulty to control the native/dominant languages of bi/multilinguals while performing in the foreign/minority language, which in turn might be triggered by various interand intra-linguistic factors.

To sum up the results presented so far, the Russian-Turkish participants do not seem to experience any difficulties in the use of the locative, ablative, genitive, instrumental and dative cases in their L2 Turkish. The nearly errorfree use of these five cases of the Russian-Turkish participants is inconsistent with the findings of the studies examining the use of cases in L2 Turkish acquisition (Gürel, 2000; Haznedar, 2006; Papadopoulou et al., 2011), which reported that their participants, who are L1 speakers of the English and Greek languages, even at very advanced levels of proficiency make numerous errors in the use of all Turkish cases. The findings of the present study allow me to speculate that the acquisition of Turkish cases by the Russian-Turkish participants might have been benefitted from the availability of the case system in their L1 Russian, which is rather complex and realization of some 
cases of which overlap to a certain extent with the Turkish case system (see discussion above). However, it is necessary to acknowledge here that this speculation is not conclusive, and further analyses of the relevant data obtained from the participants of different L1 backgrounds are required.

Now returning to the main focus of this study, that is the accusative case, the use of which requires the activation of several linguistic domains, the data analysis has revealed that the Russian-Turkish participants make numerous errors in the use of the accusative case marker. Table 9 below presents the number of the correct uses, omissions, replacements and overuses of the accusative case marker found in the data.

Table 9. The use of the accusative case markers in the production of RussianTurkish bilinguals

\begin{tabular}{llllllll}
\hline Participants & 1 & 2 & 3 & 4 & 5 & 6 & 7 \\
\hline Total use (100\%) & 26 & 17 & 27 & 29 & 18 & 13 & 18 \\
Correct use & 20 & 15 & 20 & 25 & 13 & 11 & 15 \\
Correct use (\%) & 77 & 88 & 74 & 86 & 72 & 85 & 83 \\
Omission & 5 & 2 & 6 & 4 & 4 & 2 & 2 \\
Omission (\%) & 0 & 0 & 0 & 0 & 0 & 0 & 0 \\
Replacement & 1 & 0 & 0 & 0 & 0 & 0 & 1 \\
Replacement (\%) & & 0 & & & & 0 & \\
Overuse & 0 & 0 & 0 & 0 & 0 & 0 & 0 \\
Overuse (\%) & 0 & 0 & 1 & 0 & 1 & 0 & 0 \\
\hline
\end{tabular}

In order to see whether or not the use of the accusative case of the RussianTurkish participants differs significantly from their use of all other Turkish case markers and from that of the native speakers of Turkish, statistical analysis has been carried out. Firstly, to see whether the use of Turkish case markers of the Russian-Turkish participants differs for, at least, one of them, Friedman test has been applied. Friedman test reveals that, at least, one of the medians of the case marker use in the data of the Russian-Turkish participants is significantly different from all the others at $\alpha=0,05(p=0.000)$. Secondly, in order to see whether or not the percentage of the correct use of the accusative case marker of the Russian-Turkish participants is statistically less than that of all the other Turkish case markers in the data of the Russian-Turkish participants, Wilcoxon Signed Rank Test has been conducted for each pair of case markers (ACC LOC, ACC - ABL, ACC - GEN, ACC - INST, and ACC - DAT). The Wilcoxon Signed Rank Test has revealed that for each pair, the correct use of the accusative case marker is significantly less than each of the other case marker at $\alpha=0,05$ ( $p$-value of 0.009). Thirdly, five simultaneous tests have overall $p$-value of 0.045 according to Bonferroni, which indicates that the correct use of the accusative case marker is significantly less than the use of all 
other case markers at a significance level of $\alpha=0,05$. Finally, in order to explore whether the use of the accusative case marker of the Russian-Turkish bilinguals statistically differs from that of the native speakers of Turkish, Mann-Whitney $\mathrm{U}$ test has been carried out. The test has revealed significant difference in the use of the accusative case markers between the groups $(U=14,500, p=.199)$. As such, the statistical analysis allows me to infer that the use of the accusative case of the Russian-Turkish participants does differ from their use of all other cases in Turkish as well as from the use of the accusative case of the native speakers of Turkish.

Further, the data of the Russian-Turkish participants have been examined for error patterns in the use of the accusative case marker. As it is displayed in Table 9, there are only two instances when the accusative case marker is replaced with another one. Both instances of the replacement of the accusative case marker appear with the verb aramak (call), which requires the use of the direct object with the accusative case marker in Turkish. The two Russian participants, in contrast, use the oblique object with the dative case marker in personal pronouns used with the verb aramak, as Example 17 illustrates.

(17) Akşam Juno *onlar-a ara-d1.

evening-N-M Juno-N-M *they-DAT call-PAST-3P.SG

'In the evening, Juno called them'.

The replacements of the accusative case marker with the dative one observed in the data of the Russian-Turkish participants might be attributed to their L1 influence, because the Russian verb звонить [zvonit'] (call) requires the dative case, which is also used by all the participants in their narratives written in L1 Russian.

The errors due to the replacement of the accusative case marker are single instances in the data of two participants, and they are much fewer than those due to omission of the accusative case marker, which are available in the production of each participant. Examples 18 and 19 below illustrate cases of omissions of the accusative case marker found in the production of the Russian-Turkish participants.

(18) Baba-s1-na

*haber

söyle-yip çift-in

father-POSS-DAT *news-N-M say-CON couple-GEN

ziyaret-i-ne

baba-s1-yla

git-ti-ler.

visit-POSS-DAT father-POSS-INST/COM go-PAST-3P.PL

'Having told her dad about the news, she went to visit the couple with him.' 

(19) Sonra bu *çift bul-uyor-lar. after this *couple-N-M find-IMPER-3P.PL 'After that they find this couple.'

The data analysis has revealed that the Russian-Turkish participants tend to omit the accusative case marker in the definite common nouns and they use a case non-marked form for the definite and non-definite common nouns as canonical. However, in pronouns, personal nouns and derived nominal, the omission of the accusative case marker is not observed. Moreover, all the cases of omissions of the accusative case marker occur in common nouns most of which have been mentioned by the participants in their narratives before or are used with the determiner $b u$ (this). This observation may suggest that the Russian-Turkish participants do not seem to associate the use of the accusative case marker with definiteness of common nouns in Turkish in a native-like manner, and they tend to use case non-marked forms as canonical for defined and/or previously introduced common nouns in the function of the direct object. The nearly absolute absence of errors due to the overuse of the accusative case marker in the participants' production supports this presupposition. Thus, the language behavior of the Russian-Turkish participants related to the use of the accusative case marker seems to be different from their use of all other cases in Turkish.

Though there are few errors observed in the use of the dative case marker, these errors are single instances occurring along with the correct uses of the dative case marker with the same verbal forms, which allows me to speculate that the performance of the participants here might be due to the peculiarities of bilingual acquisition and production (Grosjean, 2001; Meisel, 2007). In the use of the accusative case, on the other hand, the errors are significantly more numerous if compared with the dative case, and the absolute majority of them is of the same pattern, that is due to the omission of the accusative case marker in common nouns, which may indicate that the Russian-Turkish participants seem to have acquired the use of the accusative case marker in this particular domain incompletely, as the absolute majority of the common nouns in the data, both definite and indefinite are used without any case marker.

To finalize, the data analysis has revealed that the use of the accusative case marker of the Russian-Turkish participants, which involves multiple internal-external interfaces, is marked with fossilized errors and incomplete acquisition, while all other Turkish case markers, which do not require the activation of the external interface, are used nearly error-free. Thus, this finding validates both hypotheses stated at the beginning of the study and provides a piece of evidence in favor of the IH. 
As it has been discussed in the introductory section of the study, there are two possible sources accounting for optionality and instability in structures vulnerable to interface conditions in L2 contexts: the influence of the L1 grammatical system and the differences between monolinguals and bilinguals at the level of processing strategies required in the use of interface structures (Sorace, 2011). It does not seem to be possible to disentangle the role of each of the sources based on the data available in the study; however, relying on the contrastive analysis of Russian and Turkish and considering that definiteness/indefiniteness is not inflected in Russian, it can be speculated that the cross-linguistic influence from L1 Russian may account for the lack of supplience of the accusative case marker in definite common nouns, and that the participants' elementary and below levels of English may appear to be insufficient for benefitting from the concept of definite/indefiniteness available in English when marking definiteness/indefiniteness of common nouns in Turkish. However, this presupposition, by no means, excludes the differences between monolinguals and bilinguals at the level of processing strategies required in the use of interface structures as another possible source of optionality and instability, but might indicate that when bilinguals deal with an internal-external interface structure, which requires more processing recourses and that is why may pose a challenge to L2 users, bilinguals seem to resort to their L1 (or other languages available in their repertoire) to overcome this challenge.

\section{Conclusion}

This study investigating the use of Turkish cases of the Russian-Turkish bilinguals, who are very proficient users of Turkish, has provided a piece of evidence confirming the $\mathrm{IH}$, according to which interface structures involving internal and external interfaces are likely to be vulnerable to incomplete acquisition and/or fossilization. The following limitations of the study should be mentioned: first, the study is based on the written data, which allows more time for processing if compared with spontaneous speech production and might affect the accuracy of case use of the participants; second, the data have been collected from the limited number of participants, therefore, all the findings should be interpreted with caution and need further validation.

\section{References}

Akdoğan, G. (1993). Yabancıların Türkçe Öğreniminde Ad Durumu ve Çekim Açısından Sik Rastlanan Yanlışlar ve Nedenleri. MA Thesis, Ankara University, Ankara.

Aksu-Koc, A. \& Ketrez, F. N. (2003). Acquisition of Noun and Verb Categories in Turkish, In S. Özsoy, D. Akar, D. Nakipoglu, E. Erguvanl1-Taylan and A. Aksu- 
Koç, (Eds.) Studies in Turkish Linguistics, 239-246. Istanbul: Boğaziçi University Press.

Aksu-Koç, A. \& Slobin, D. I. (1985). The Acquisition of Turkish. In D. I. Slobin (Ed.), The Crosslinguistic Study of Language Acquisition, 839-880. Hillsdale, NJ Lawrence Erlbaum Associates.

Akyol, Ö. (2009). Acquisition of Turkish by a Bilingual Child: A Case Study. Unpublished MA Thesis. Çukurova University, Adana.

Altunkol, E. \& Balc1, B. (2013). The Usage of Turkish Grammatical Morphemes by Learners of Turkish As a Second Language. Athens: Atiner's Conference Papers Series, No: Lng2013-0711.

Belletti, A., Bennati, E. \& Sorace, A. (2007). Theoretical and Developmental Issues in the Syntax of Subjects: Evidence from Near-Native Italian. Natural Language and Linguistic Theory, 25, 657-689.

Berman, R. A. (1999). Bilingual Proficiency/Proficient Bilingualism. Insights from Narrative Texts. In G. Extra \& L. Verhoeven (Eds.), Bilingualism And Migration, 187- 208. Berlin: Mouton De Gruyter.

Comrie, B. (1987). The World's Major Languages. London: Routledge.

Corbett, G. (1982). Gender in Russian: An Account of Gender Specification and its Relationship to Declension." Russian Linguistics 6, 197-232.

Corbett, G. (1991). Gender. Cambridge: Cambridge University Press.

Corbett, G. \& Fraser, N. (1993). Network morphology: A DATR Account of Russian nominal inflection. Journal of Linguistics 29 (1), 113-142.

Ekmekçi, Ö. (1979). Acquisition of Turkish: A Longitudinal Study on the Early Language Development of a Turkish Child. Ph.D. Diss., University of Texas, Austin.

Enç, M. (1991). The semantics of Specificity. Linguistic Inquiry 22 (1), 1-25.

Erguvanl1, E. (1984). The Function of Word Order in Turkish Grammar. Berkeley and Los Angeles: University of California Press.

Göksel, A. (1993). Levels of Representation and Argument Structure in Turkish. Doctoral dissertation, Department of Linguistics, School of Oriental and African Studies, University of London.

Göksel, A. \& Kerslake, C. (2005). Turkish: A Comprehensive Grammar. London: Routledge.

Grosjean, F. (2001). The Bilingual's Language Modes. In J. Nicol (Ed.), One Mind, Two Languages: Bilingual Language Processing, 1-22. Oxford, UK: Blackwell.

Gürel, A. (2000). Missing Case Inflection: Implications for Second Language Acquisition. In C. Howell, S. A. Fish \& K. L. Tea (Eds.), Proceedings of the $24^{\text {th }}$ Annual Boston University Conference on Language Development 45, 379-390. Somerville, MA: Cascadilla Press.

Güven, E. (2007). Yabancıların Türkçe Öğrenirken Ad Durum Eklerinde Yaptıkları Hataların Çözümlenmesi ve Bu Hataların Giderilmesine Yönelik Öneriler. MA Thesis, Dokuz Eylül University, Izmir.

Haznedar, B. (2006). Persistent Problems with Case Morphology in L2 acquisition. In C. Lleó (Ed.), Interfaces in Multilingualism, 179-206. Amsterdam: John Benjamins.

Haznedar, B. (2007). Crosslinguisitic influence in Turkish-English Bilingual First Language Acquisition: The Overuse of Subjects in Turkish. Proceedings of the $2^{\text {nd }}$ Conference on Generative Approaches to Language Acquisition North America (GALANA), 124-134. Somerville, MA: Cascadilla Proceedings Project.

Hopp, H. (2004). Syntactic and Interface Knowledge in Advanced and Near-Native Interlanguage Grammars. In S. Foster-Cohen, M. Sharwood Smith, A. Sorace, \& M. Ota (Eds.), Eurosla Yearbook 4, 67-94. Amsterdam: John Benjamins.

Ivanov, I. (2009). Second Language Acquisition of Bulgarian Object Clitics: A Test 
Case for the Interface Hypothesis. Phd Diss., University of Iowa. Http://Ir.Uiowa.Edu/Etd/300.

Kamynina, A. 1999. Sovremennyi Russkij Jazyk. Morfologija. (Modern Russian language. Morphology). Moscow: Moskovskij Universitet.

Ketrez, F. N. (2004). Children's Accusative Case and Indefinite Objects. Dilbilim Arastırmaları, 63-73. Istanbul.

Ketrez, F. N. (2005). Children's Scope of Indefinite Objects and Negation. Proceedings Volume of ICTL 2004: 12th International Conference on Turkish Linguistics, Dokuz Eylül University, Izmir, Turkey, August 11-13.

Ketrez, F. N. (2006). A Case-study on the Accusative Case in Turkish. WECOL 2004, 163-174

Kornfilt, J. (1997). Turkish. London, UK/New York, NY: Routledge

Kupersmitt, J. \& Berman, R. (2001). Linguistic Features of Spanish-Hebrew Children's Narratives. In L. Verhoeven \& S. Strömqvist (Eds.), Narrative Development in a Multilingual Context, 277-319. Amsterdam/Philadelphia: John Benjamins Publishing Company.

Kurilovich, E. (1962). Ocherki po Lingvistike. (Linguisitic essays). Moskva: Inostrannaya Literature.

Lanza, E. (2001). Temporality and Language Contact in Narratives by Children Bilingual in Norwegian and English. In L. Verhoeven \& S. Strömqvist (Eds.), Narrative Development in a Multilingual Context, 15-55. Amsterdam/Philadelphia: John Benjamins Publishing Company.

Lozano, C. (2006). The Development of the Syntax-Information Structure Interface: Greek Learners of Spanish. In V. Torrens \& L. Escobar (Eds.), The Acquisition of Syntax in Romance Languages, 371-399. Amsterdam/Philadelphia: John Benjamins.

Margaza, P. \& Bel, A. (2006). Null Subjects at the Syntax-Pragmatics Interface: Evidence from Spanish Interlanguage of Greek Speakers. In M. G. O'Brien, C. Shea \& J.Archibald (Eds.), Proceedings of GASLA 2006, 88-97. Somerville, MA: Cascadilla Press.

Meisel, J. (2007). The Weaker Language in Early Child Bilingualism: Acquiring a First Language as a Second Language? Applied Psycholinguistics 28, 495-514.

Mueller, N. \& Hulk, A. (2001). Crosslinguistic Influence in Bilingual Language Acquisition: Italian and French as Recipient Languages. Bilingualism: Language and Cognition 4(1), 1-21.

Nakipoğlu, M. (2009). The Semantics of the Turkish Accusative Marked Definites and the Relation between Prosodic Structure and Information Structure. Lingua 119 (9), 1253-1280.

Öztürk, B. (2005). Case, Referentiality, and Phrase Structure. Amsterdam/Philadelphia: John Benjamins.

Öztürk, B. (2009). Incorporating Agents. Lingua, 119(2), 334-358.

Papadopoulou, D., Varlokosta, S., Spyropoulous, V., Kaili, H., Prokou, S. \& Revithiadou, A. (2011). Case Morphology and Word Order in Second Language Turkish: Evidence from Greek Learners. Second Language Research 27, 173-205.

Paradis, J. \& Navarro, S. (2003). Subject Realization and Crosslinguistic Interference in the Bilingual Acquisition of Spanish and English: What is the Role of Input? Journal of Child Language 30, 1-23.

Pavlenko, A. (2003). "I Feel Clumsy Speaking Russian"; L2 Influence on L1 in Narratives of Russian L2 Users of English. In V. Cook (Ed.), Effects of the Second Language on the First, 32-61. Clevedon, UK: Multilingual Matters.

Rothman, J. (2008). How Pragmatically Odd!: Interface Delays and Pronominal Subject Distribution in the L2 Spanish of English Natives. Studies in Hispanic and 
Lusophone Linguistics 1, 2, 317-339.

Sorace, A. (2011). Pinning Down the Concept of Interface in Bilingualism. Linguistic approaches to bilingualism 1 (1), 1-34.

Sorace, A. (2012). Pinning Down the Concept of Interface in Bilingualism. A Reply to Peer Commentaries. Linguistic approaches to bilingualism 2 (2), 209-216.

Sorace, A. \& Filiaci, F. (2006). Anaphora Resolution in Near-Native Speakers of Italian. Second Language Research, 339-368.

Sorace, A., Serratrice, L., Filiaci, F. \& Baldo, M. (2009). Discourse Conditions on Subject Pronoun Realization: Testing the Linguistic Intuitions of Bilingual Children. Lingua 119, 460-477.

Sorace, A. \& Serratrice, L. (2009). Internal and External Interfaces in Bilingual Language Development: Beyond Structural Overlap. International Journal of Bilingualism 13 (2), 195-210.

Timberlake, A. (2004). A Reference Grammar of Russian. Cambridge: Cambridge University Press.

Topbaş, S., Maviş, İ. \& Başal, M. (1996). Acquisition of Bound Morphemes: Nominal Case Morphology in Turkish. In K. İmer \& E. Uzun (Eds). VIII. Uluslar arası Türk Dilbilimi Konferansı Bildiri Kitabı. Ankara Üniv. Yay.

Tsimpli, T., Sorace, A., Heycock, C. \& Filiaci, F. (2004). First Language Attrition and Syntactic Subjects: A Study of Greek and Italian Near-native Speakers of English. International Journal of Bilingualism 8, 257-277.

Tsimpli, I. M. \& Sorace, A. (2006). Differentiating Interfaces: L2 Performance in Syntax-Semantics and Syntax-Discourse Phenomena. Proceedings of the Annual Boston University Conference on Language Development 30, 653-664.

Van der Heijden, H. \& Verhoeven, L. (1994). Early Bilingual Development of Turkish Children in the Netherlands. In G. Extra \& L Verhoeven (Eds.), The Cross-linguisitc Study of Bilingual Development, 51-73. Amsterdam: Koninklijke Nederlandse akademie van Wetenschappen.

Viberg, A. (2001). Age-Related and L2-Related Features in Bilingual Narrative Development in Sweden. In L. Verhoeven \& S. Strömqvist (Eds.), Narrative Development in a Multilingual Context, 15-55. Amsterdam/Philadelphia: John Benjamins Publishing Company.

White, L. (2003). Fossilization in Steady State L2 Grammars: Persistent Problems with Inflectional Morphology. Bilingualism: Language and Cognition 6, 129-141.

White, L. (2007). Linguistic Theory, Universal Grammar and Second Language Acquisition. In B. van Patten \& J. Williams (Eds.), Theories in second language acquisition: an introduction (pp. 37-55). Lawrence Erlbaum. 